\title{
Tectonic imprints within a granite exposed near Srinagar, Rajasthan, India
}

\author{
Trishit Ruj and Nilanjan Dasgupta* \\ Department of Geology, Presidency University, 86/1 College Street, Kolkata 700 073, India. \\ ${ }^{*}$ Corresponding author.e-mail: neelakdg@gmail.com ndg.geol@presiuniv.ac.in
}

Partial melting in the middle to lower crustal level produces melts of granitic composition during orogeny. Thrusts play a vital role in their exhumation after consolidation of these granitic melts. In this paper we focus on one such granite along the eastern margin of the Delhi Fold Belt (DFB) rocks near Srinagar, Rajasthan, India. This is the first report of granite within the area and holds a key stratigraphic position in the entire rock package. The said granite is found to be intrusive to the DFB metasediments as well as their basement popularly known as the Banded Gneissic Complex (BGC). We disentangle the deformation fabrics seen within the granite and associated DFB metasediments, suggesting that subsequent to emplacement and consolidation, the granite has co-folded along with the country rocks. Three deformational events could be identified within the DFB metasediments namely, $\mathrm{D}_{1 \mathrm{D}}, \mathrm{D}_{2 \mathrm{D}}$ and $\mathrm{D}_{3 \mathrm{D}}$. The peak metamorphism was achieved in the $\mathrm{D}_{1 \mathrm{D}}$ event. The granite magma is generated and emplaced late syn-kinematic to $\mathrm{D}_{1 \mathrm{D}}$ and thereafter is deformed by $\mathrm{D}_{2 \mathrm{D}}$ and $\mathrm{D}_{3 \mathrm{D}}$ producing $\mathrm{D}_{1 \mathrm{G}}$ and $\mathrm{D}_{2 \mathrm{G}}$ structural fabrics. These compressive deformations resulted in the collapse of the basin; the combined package of DFB rocks and the granite was thrusted eastwards over the basement rocks. The tectonic transport direction during thrusting is suggested eastwards from our structural analysis. Transverse faults developed perpendicular to the length of the granite have led to partitioning of the strain thereby showing a heterogeneity in the development of fabric within it.

\section{Introduction}

The Delhi Fold Belt (DFB) rocks are exposed along the axial regions of the Aravalli fold mountain belt extending from Delhi in the north to Gujarat in the south through Rajasthan in an hourglass shaped outcrop pattern (Gupta and Bose 2000; Gupta 2004). The southern part of DFB rocks (often referred to as South DFB, SDFB; Sinha Roy 1984) is intruded by numerous granite bosses and stocks, a majority of which are concentrated within the western segment of the SDFB. The granitic injections found within the DFB rocks are mainly distributed in three time zones: around 1470 Ma (Gopalan et al. 1979; Choudhary et al. 1984;
Tobisch et al. 1994; Fareeduddin and Kroner 1998) followed by 1.0 Ga (Volpe and MacDougall 1990; Deb et al. 2001) and thereafter around $850 \mathrm{Ma}$ (Choudhary et al. 1984; Volpe and MacDougall 1990). There are scanty evidences of granite/ granitoid injections along the eastern boundary of the DFB rocks, especially within the SDFB. The only example of granite-pegmatite along the eastern margin of DFB south of Ajmer was reported by Dasgupta et al. $(2009,2011)$ from the vicinity of Bayalan, near Beawar about $100 \mathrm{~km}$ south from the present study area.

Heron (1953) described a thick sequence of metasedimentary rocks unconformably overlying the basement gneisses from the area. His succession

Keywords. Granite emplacement; collisional setting; thin-skinned tectonics; thrust-related emplacement; Delhi Fold Belt. 
included a basal conglomerate overlain by calc schists, argillites, and quartzite. He did not mention the occurrence of any granite from the area. The presence of thick conglomerate along the eastern margin is a rare feature in the DFB rocks unlike the western margin of DFB, where Heron (1953), Murthy and Bhargava (1972), Biswal (1993) and Dasgupta et al. (2012) have reported a thick persistent band of conglomerate known as the Barr conglomerate separating the DFB rocks from the basement gneisses to its west. There are scanty occurrences of conglomerate reported along the eastern margin of the DFB rocks, the only other being at Badnor $\left(74^{\circ} 16^{\prime} 58.32^{\prime \prime} \mathrm{E}, 25^{\circ} 50^{\prime} 2.48^{\prime \prime} \mathrm{N}\right.$, south of the present area), where the conglomerate at the base of DFB rocks lies unconformably over the basement gneisses (Mukhopadhyay and Dasgupta 1978).

It is the presence of the conglomerate that drew our attention and though we found bands of conglomerate within the high hills along the eastern margin near Srinagar $\left(74^{\circ} 46^{\prime} 39.5^{\prime \prime} \mathrm{E}, 26^{\circ} 26^{\prime} 03.5^{\prime \prime} \mathrm{N}\right)$, most of these high hills are of granite and is being reported for the first time. With this perspective we explore the granite, seen to have intruded into the basement and the cover DFB rocks, and subsequently co-folded with the DFB metasediments, around Srinagar. The only other occurrence of granite along the eastern margin of DFB south of Ajmer was reported by Dasgupta et al. $(2009,2011)$ from the vicinity of Bayalan, near Beawar about $100 \mathrm{~km}$ south from the present study area.

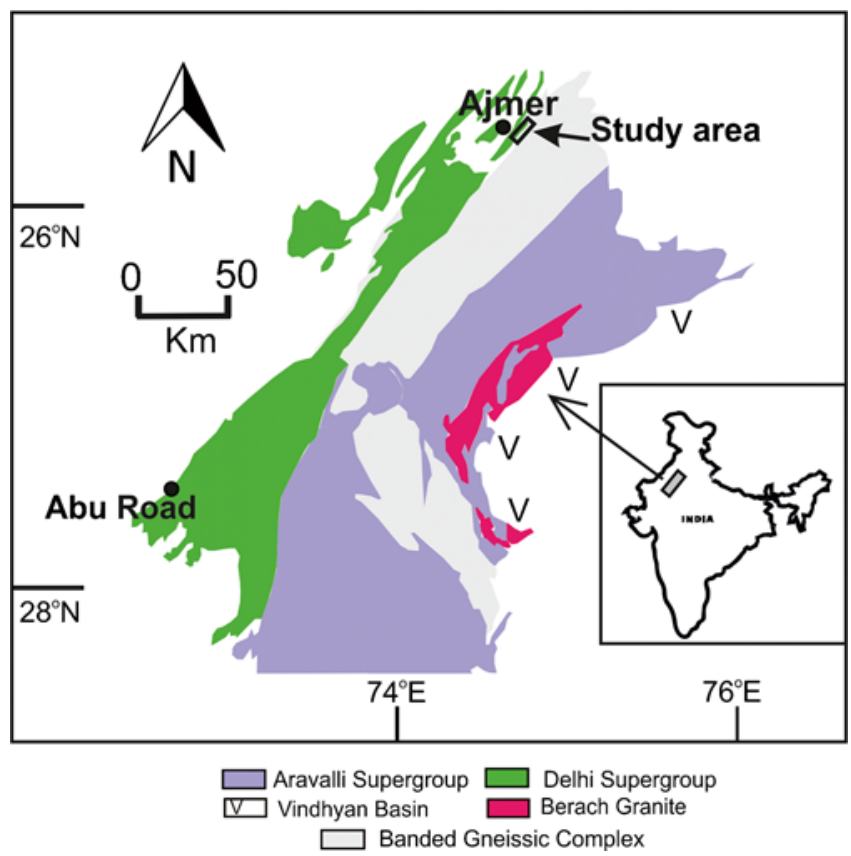

Figure 1. Geological map showing the broad lithostratigraphic subdivisions of south central Rajasthan, as envisaged by Heron (1953). The arrow marks the location of the study area near Ajmer.
The present area (figure 1) therefore, demanded a thorough geological mapping with the objective of unraveling the deformation style in the DFB rocks (and its correlation with reports elsewhere), timing of granite formation, and tectonic evolution of the rocks along the eastern margin of DFB. This part of our study highlights the Precambrian tectonics involved and discusses the nature of evolution of the eastern margin with the western margin of the DFB rocks. It is worth mentioning here that Sinha-Roy $(1988,2004)$ introduced the concept of plate tectonics which he thought was operative in the Precambrian rocks of this terrane.

\section{The Srinagar granite and associated metasediments: the map pattern}

The lithologic map of the area (figure 2) reveals that the metasedimentary rock package of DFB in the study area comprises a basal polymictic conglomerate overlain successively by calc-silicate gneiss, pelitic schist of diverse mineralogies (biotite schist, garnet schist, and staurolite schist, forming a partial Barrovian sequence of metamorphism), quartz-biotite schist and quartzite. The

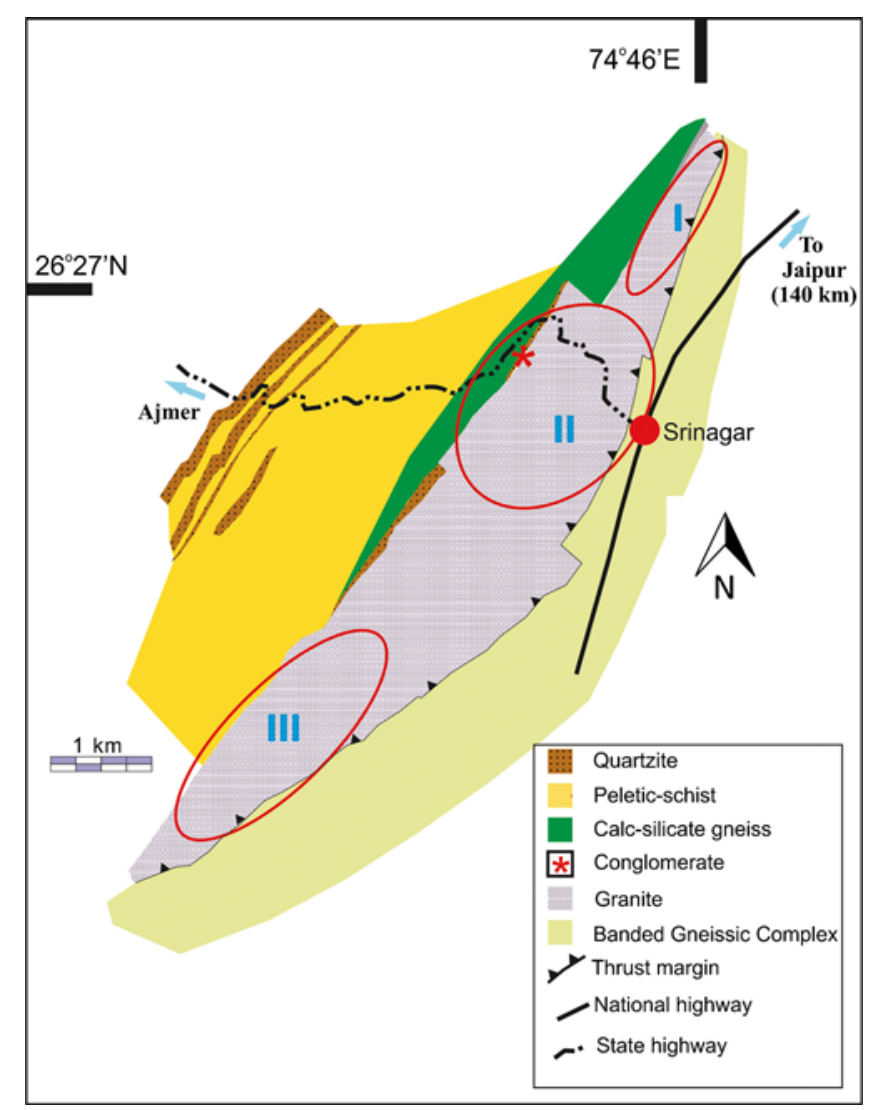

Figure 2. Lithologic map of the study area. Note that the granite is subdivided into three sectors, namely I, II and III for structural analyses (refer text for details). 
entire metasedimentary package is separated by granite from its basement composed of amphibolite gneiss and migmatite to the west.

The granite occupies the high hill ranges around Srinagar with a plano-convex outcrop pattern; straight western margin and a convex eastern margin. There are faults dipping $70^{\circ}$ towards ENE, transverse to the length of the granite outcrop. The intrusive nature of the granite is established by the presence of conglomerate rafts (figure 3a) and apophyses (figure $3 \mathrm{~b}$ ) injected into the calc gneiss. Within the basement gneiss, tongues of granite are also observed (figure 3c).

West of the Srinagar granite, the metasediments of DFB occur as bands, folded into asymmetric dextral folds, whose long limbs trend NNESSW. This conforms to the regional structural grain of the DFB rocks (reported from the Ajmer
Beawar region) which is controlled by folds having NE-SW to NNE-SSW trending axial planes and generally shallow plunges with culminations and depressions (Sengupta 1988; Mukhopadhyay 1989; Mukhopadhyay and Matin 1991; Naha et al. 1984; Naha and Mohanty 1988). Bands of quartzite stand out from amidst the pelitic schist and form hill ranges, which facilitate as marker horizons for deciphering the regional structure. There are three generations of fold forms as we shall discuss in later sections. The basement rocks occupying the lowland regions to the east of the granite are biotite gneiss mostly with a few occurrences of quartzite and dark coloured hornblende biotite gneiss. These lithologies are complexly folded (the fold pattern completely different from the folds observed within DFB metasediments), often migmatised and have a very poor exposure quality compared to the well

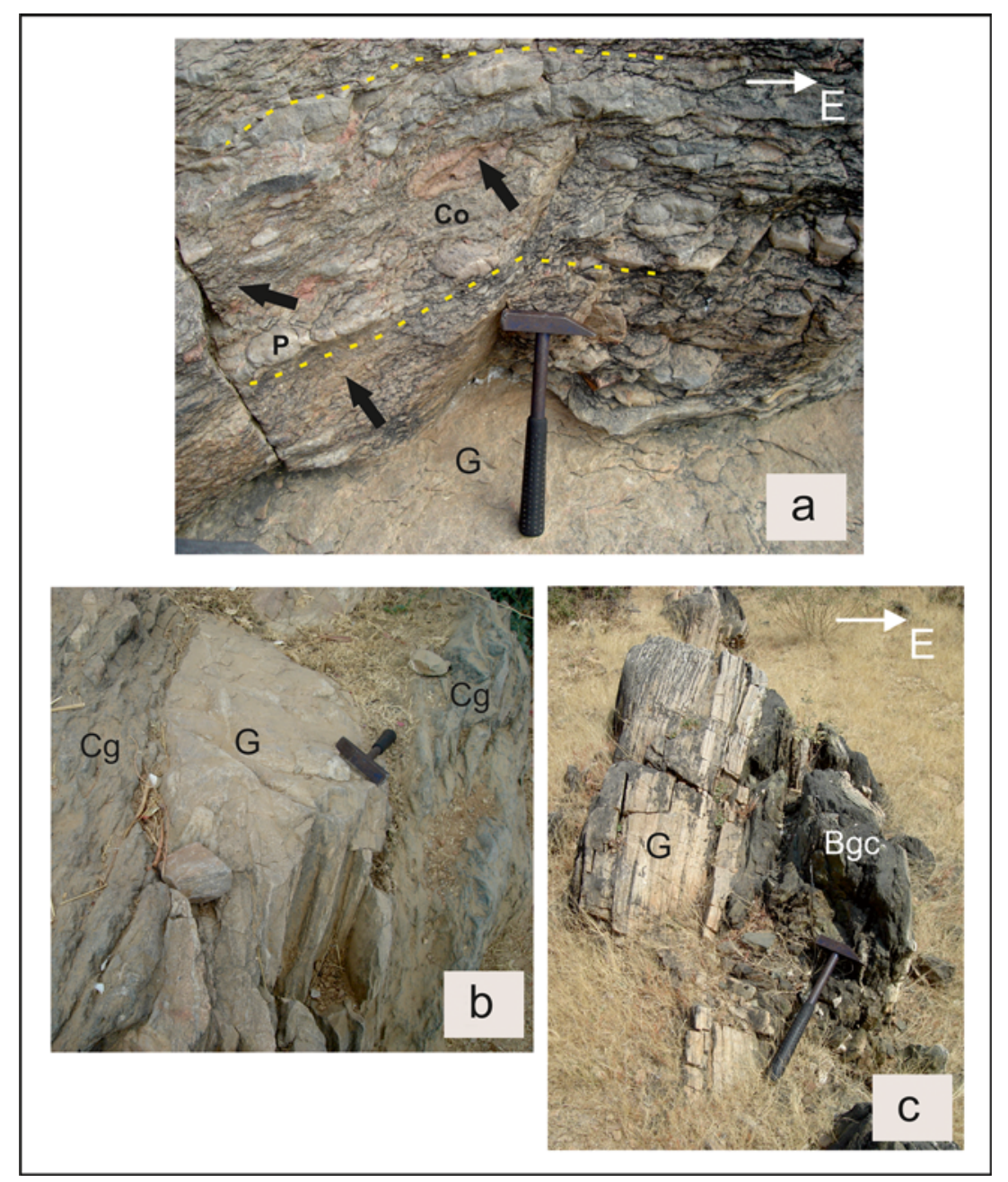

Figure 3. (a) Meter scale raft of conglomerate (bounded by yellow coloured dotted line and marked Co) with quartzite pebbles $(\mathrm{P})$, trapped within granite $(\mathrm{G})$ west of Srinagar along a section looking from south. Note the thin tongues of granite intrusive along the schistosity planes within the matrix (marked by arrow). (b) Tongue of light coloured granite (G) emplaced in spaces within foliations of calc silicate gneiss $(\mathrm{Cg})$, revealing the intrusive character of the granite. Hammer head points towards southwest. (c) Granite $(G)$ intrusive into dark basement Banded Gneissic Complex (Bgc), in lit par lit fashion east of Srinagar, looking from south. 
exposed DFB metasediments. It is evident from comparing the geometry of the folds within the basement gneisses and the DFB rocks that the basement gneisses remained unaffected by the DFB orogenies, at least in the present area. The separating surface of BGC and the DFB rocks acted as a decollement surface during the Delhi orogeny. As the main focus of the present study is to bring out the tectonic imprints within the DFB rocks and the Srinagar granite and their interrelation, the detailed structural analysis of the BGC is not dicussed.

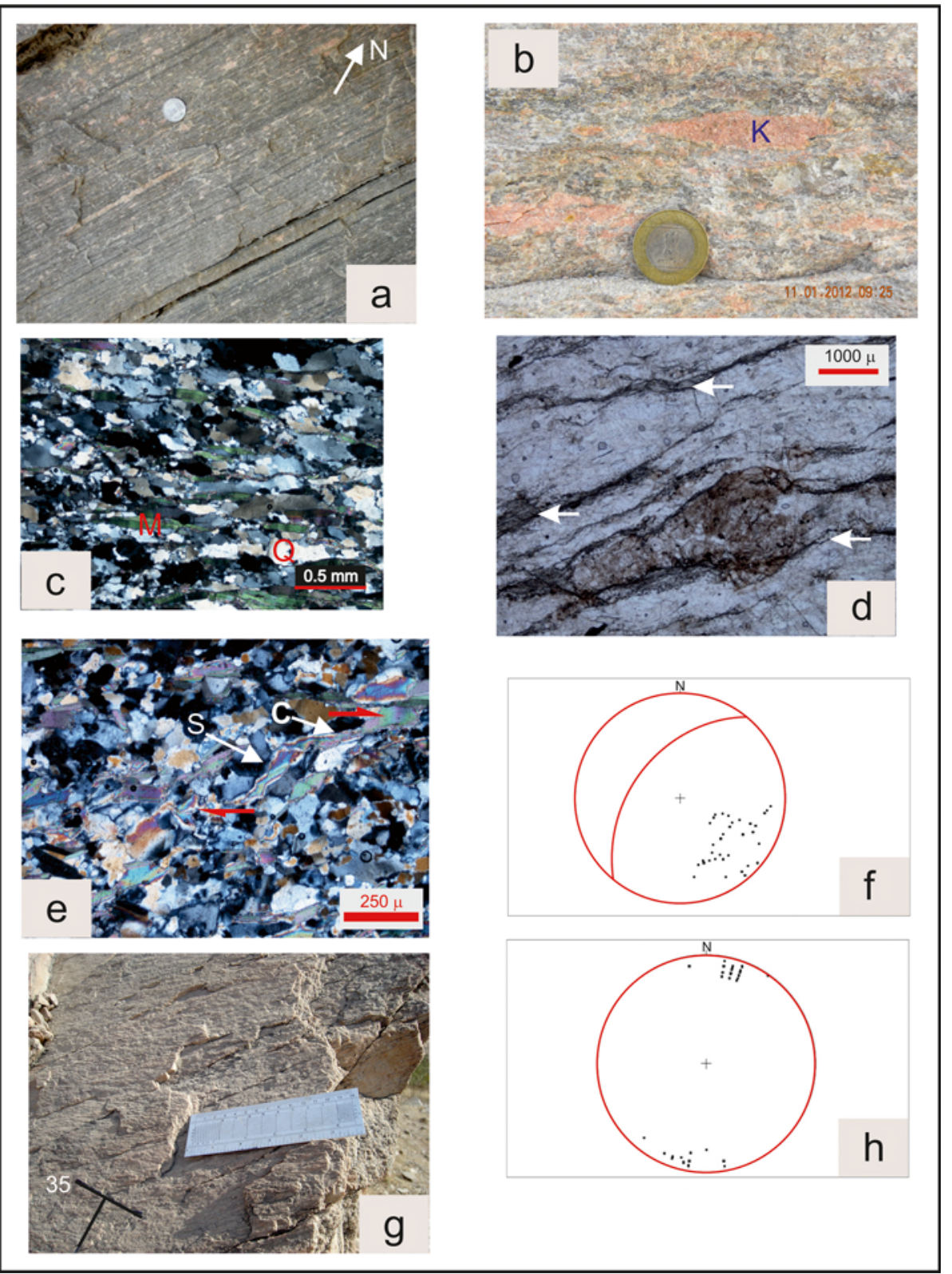

Figure 4. Characteristics of sheared granite in sectors I and III. (a) Laminated and mylonitised granite observed north of Srinagar within sector I, on plan. The mylonitic banding is developed due to intense shearing the rock has been subjected to. Diameter of the coin is 1.1 inches. (b) Elongated K-feldspar megacryst having irregular outlines but oriented parallel to the mylonitic foliation observed in (a). Patches of septa of dark coloured biotite aligned parallel to it represents primary foliation preserved as relicts within the rock ( $\mathrm{K}$ stands for K-feldspar). (c) Photomicrograph of mylonitic foliation seen within the granite in (a) ( $\mathrm{Q}$ - quartz and M - muscovite). (d) Anastomosing pressure solution seams (marked by arrow) composed of secondary fine grained phyllosilicates and opaque minerals, within the granite mimicking the mylonitic foliation, seen in the deformed granite. (e) S-C fabric defined by muscovite grains, showing a dextral asymmetry. (f) Equal area projection of 49 poles to mylonitic banding showing a point concentration. (g) Mineral lineations defined by stretched quartz grains seen on the mylonitic foliation plunging northeasterly. Note that the northeastern strike end of the foliation surface is marked. (h) Equal area projection of 54 shallow plunging lineations of stretched quartz coeval to $\mathrm{D}_{1 \mathrm{G}}$ and $\mathrm{D}_{2 \mathrm{G}}($ refer text for description). 


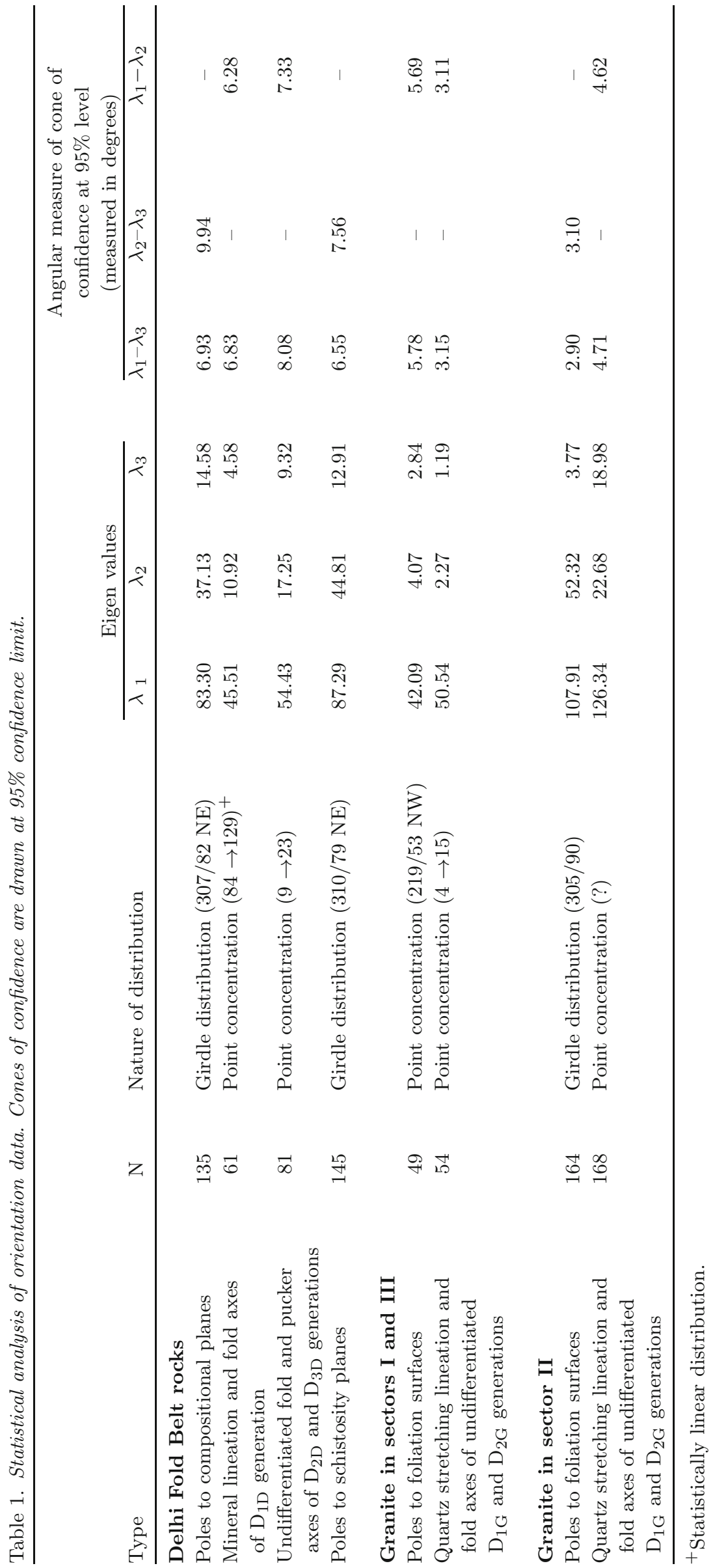




\section{Detailed structural analysis}

It has been shown that within the western segment of the SDFB, near Sendra, the intrusion of Chang granite within the metasediments has reoriented the foliations within the meta-sediments in its immediate vicinity (Gangopadhyay and Mukhopadhyay 1984), but away from the intrusion the sediments retain their structural grain. Following the same algorithm, structural geology investigations were carried out in the granite as well as in the associated DFB rocks of the area. The structural pattern of DFB rocks was worked out from areas away from the granite, where the minimal effect of emplacement is experienced. Alongside, the structural pattern within the granite was studied to have an idea of the deformations recorded within the granite. A systematic comparison of structural styles and time relationship of the deformation episodes observed within the metasediments and the granite was thereafter established. This led to the building up of a tectono-stratigraphic evolution of the rocks of the area.
In the following account, we describe the granite first and then the DFB rocks.

\subsection{Structural geometry of Srinagar granite}

The entire granite exposure was divided into three sectors on the basis of homogeneity in the development of the planar fabric within the granite (figure 2). The granite exposed in the central sector II, is more coarse grained with a weakly developed foliation and has maximum outcrop width. The two other sectors I and III within the granite, are wedge-shaped, located north and south of sector II respectively, show cleavage, and are sheared.

\subsubsection{Granite in sectors I and III}

The granite is strongly foliated and lineated and is relatively fine grained in these sectors (figure 4a). The foliation is composite in nature, mostly secondary but retains its magmatic nature at places, as some of the megacrysts (which are rare in
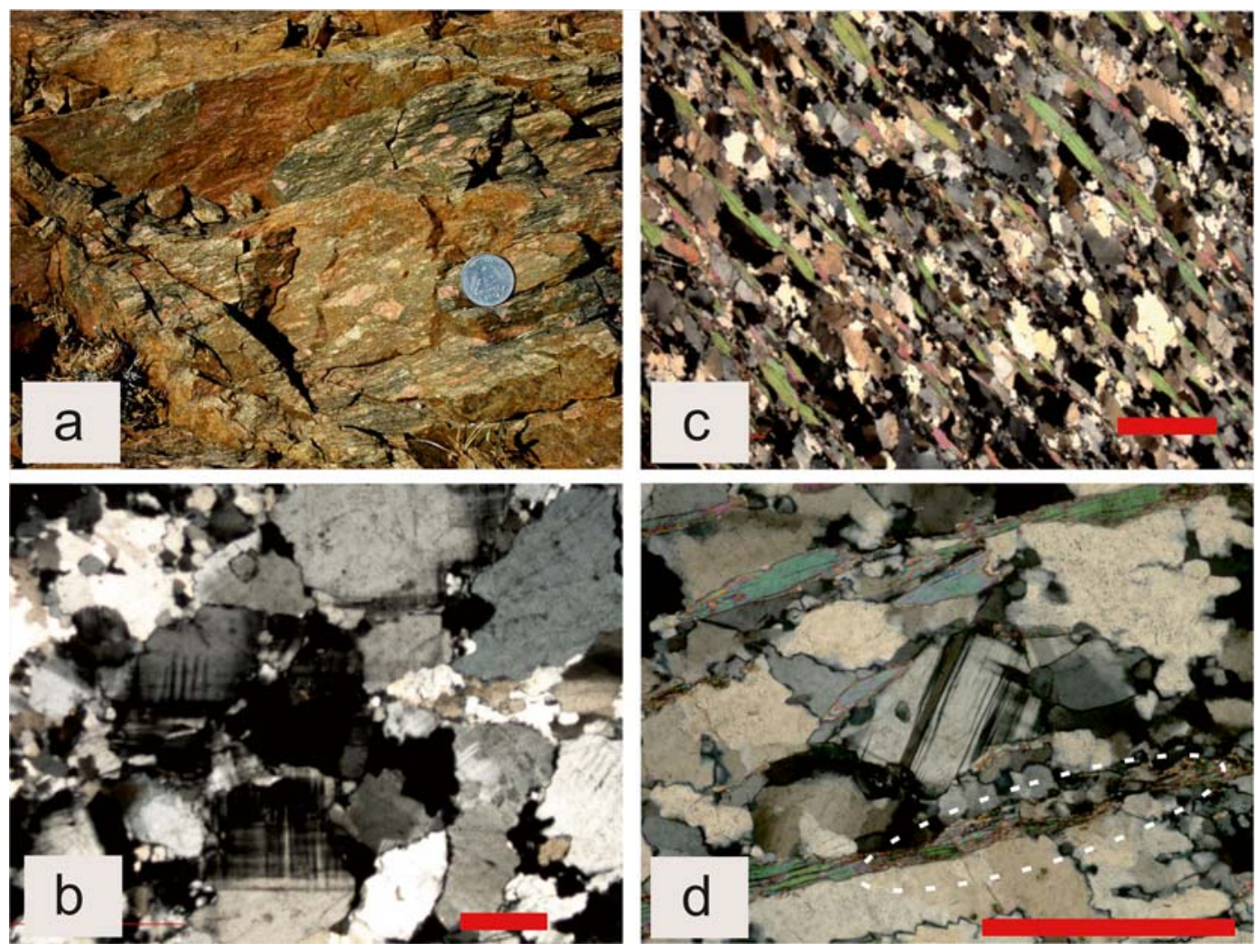

Figure 5. Petrographic features of the granite exposed in sector II. Note the bars in b, c and d represent a length of 500 microns. (a) Megacrysts of K-feldspar within the granite. Note that some of the megacrysts are aligned either parallel or are athwart to the foliation. (b) Coarse-grained granite showing relict interlocking texture between the grains. (c) The foliation seen in (a) under the microscope is formed by parallel alignment of muscovite flakes. Some of these flakes may depict the primary foliation now transposed to the deformation induced fabric. (d) Protomylonitic fabric visible in the granite along narrow zones (one such zone encircled). Note that the larger muscovite grains are parallel to this foliation. 
occurrence) are aligned parallel to it showing a directional affinity in plan and in section (figure $4 \mathrm{~b}$ ). This foliation is a mylonitic banding (figure 4a), steeply dipping towards WNW, the fabric even visible under the optical microscope (figure 4c). A protomylonitic fabric is noticeable in thin sections with percolation of pressure solution seams (filled with opaques and secondary mica, figure 4d) along two orientations; arrangement of muscovite grains hint to a development of a $\mathrm{S}-\mathrm{C}$ fabric in the rock (figure 4e), which in turn reflect shearing and associated dynamic recrystallization within quartz. A stretching lineation of quartz on this mylonitic foliation has a shallow
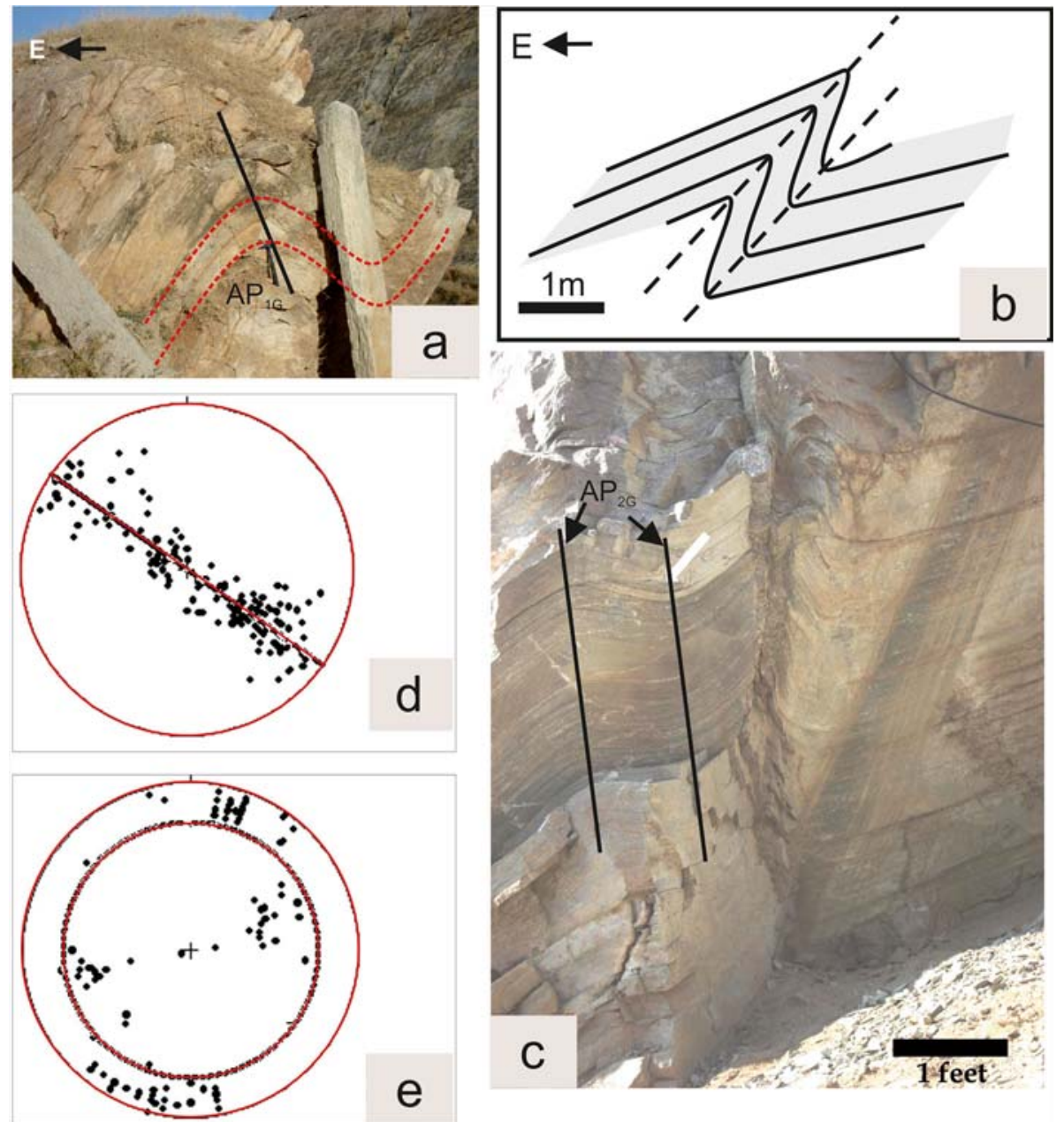

e
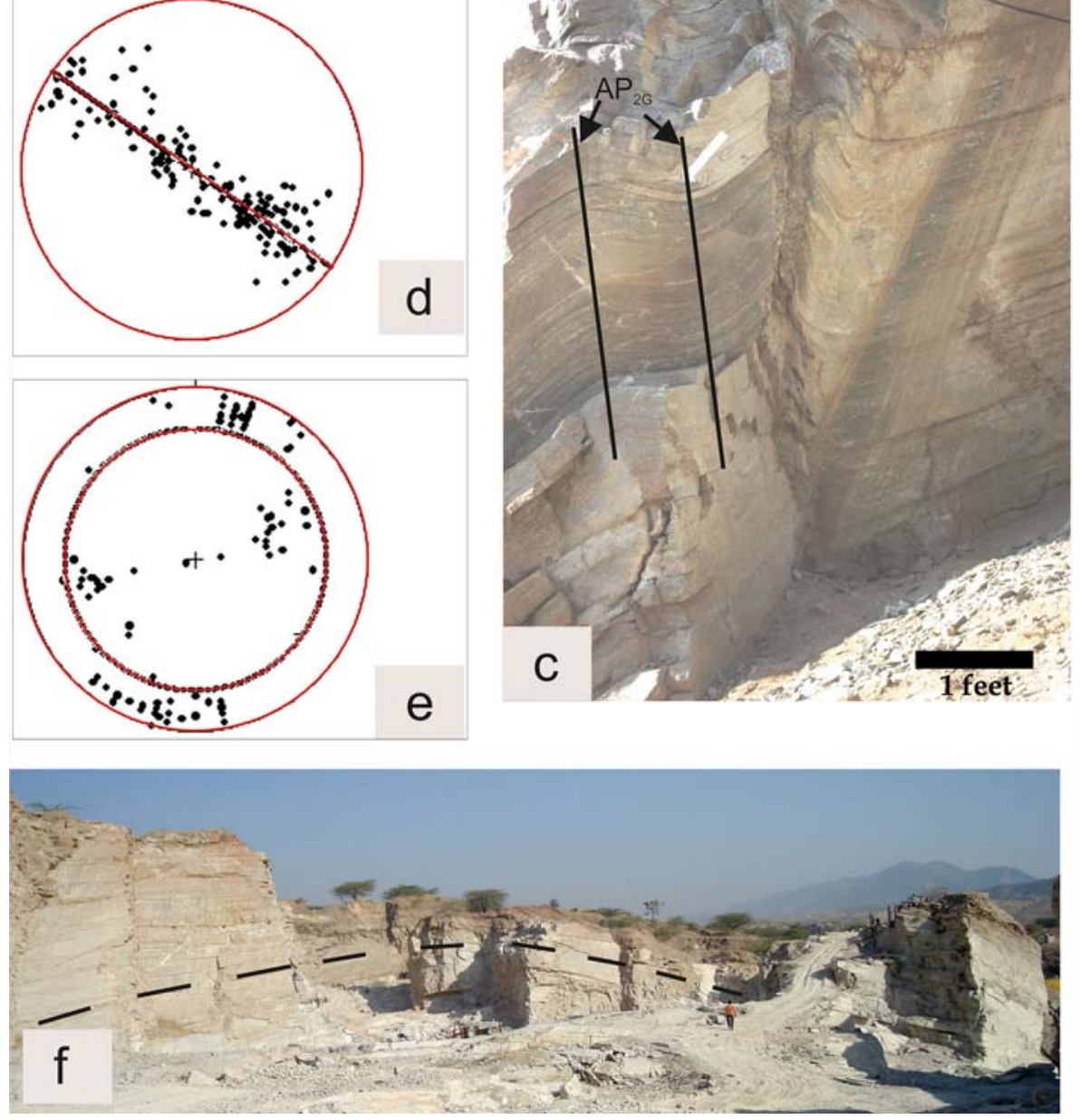

Figure 6. Structural styles within granite in sector II. (a) Asymmetric $\mathrm{D}_{1 \mathrm{G}}$ antiform and synform within granite having an easterly vergent axial plane along a section looking from north. (b) Hand sketch showing the geometry of the trains of folds of $\mathrm{D}_{1 \mathrm{G}}$ generations with a steep easterly dipping limb and gently westerly dipping limb in an outcrop scale. (c) Upright folds of $\mathrm{D}_{2 \mathrm{G}}$ generation developed on the gentle limbs of $\mathrm{D}_{1 \mathrm{G}}$ folds, axial planes of $\mathrm{D}_{2 \mathrm{G}}$ are marked as $\mathrm{AP}_{2 \mathrm{G}}$. (d) Equal area projection of 164 poles to foliation planes of the granite showing girdle distribution. (e) Equal area projection of 168 fold axes and mineral lineations within granite showing variable plunges, giving a domal geometry at the central region of sector II. The inner circle is the best fit small circle representing a right circular cone and apical angle of $75^{\circ}$. (f) The arched up foliation plane within the granite in the central region of this sector giving the dome viewed from south. The traces of foliation are shown by solid lines. 
plunge either to the NNE or SSW. Poles to foliation when plotted on an equal area projection diagram show a statistical point concentration with a mean orientation of $219^{\circ} / 53^{\circ}$ northwesterly (figure 4 f, table 1). The equal area projection of the quartz stretching lineations (figure $4 \mathrm{~g}$ ) seen on the mylonitic foliation surface also shows a statistical cluster about a mean orientation of $4^{\circ}$ towards $15^{\circ}$ (figure $4 \mathrm{~h}$, table 1 ).

\subsubsection{Granite in sector II}

The granite in this sector is foliated only along its margins but otherwise it is massive. As one moves towards the core of the granite from marginal parts in more massive variety of granite in this sector, xenoblastic to subidioblastic crystals of pinkish K-feldspar are seen having dimensions varying from a few to tens of centimeters (figure 5a). The feldspar megacrysts are generally a collection of large grains of K-feldspar, quartz, and plagioclase having a relict interlocking texture (figure 5b) indicative of its igneous parentage. From a distance these grains look like pebbles (figure 5a) embedded within a fine grained quartzo-feldspathic matrix, the rock resembling a conglomerate. The foliation is a spaced cleavage, composite in nature as it retains its primary magmatic nature locally, which gets accentuated by subsequent metamorphism. The fabric is generally recrystallized with some domainal mylonitisation effects (figure 5c). There are a few narrow brittle shear bands which are mostly westerly dipping, along which the granite has been transformed into a very fine grained non-cohesive gouge type mass.

Within the foliated granite near the margins, the secondary planar fabric resulting out of this deformation is more conspicuous and pervasive, defined by parallel alignment of biotite and muscovite flakes (figure 5d).

The foliation plane in granite is folded into a train of broad hinged non-plunging antiforms and synforms. Two deformation regimes are identified within the granite, namely $\mathrm{D}_{1 \mathrm{G}}$ and $\mathrm{D}_{2 \mathrm{G}}$, the former responsible for development of the foliation while the latter folds it. The second deformation $\mathrm{D}_{2 \mathrm{G}}$ has produced a series of upright to inclined open antiformal and synformal folds often with an easterly vergence (figure $6 \mathrm{a}, \mathrm{b}$ and $\mathrm{c}$ ). At different outcrops within the granite in this sector, one finds folds congruous to this geometry in a mesoscopic scale with a spaced schistosity, developed axial planar to these folds. The $\mathrm{D}_{2 \mathrm{G}}$ folds are either gently plunging $\mathrm{NNE}$ or SSW. The equal area projection of poles to foliation planes within the granite show a girdle distribution, with a horizontal $\beta$ trending $35^{\circ}-215^{\circ}$ (figure $6 \mathrm{~d}$, table 1 ). The plots of lineations are variable (figure 6e). At the central portion of this sector, the granite is seen to be arched up into a domal shape (figure 6f) with traceable major axial surfaces of $\mathrm{D}_{2 \mathrm{G}}$ generation in this sector (figure 7).

\subsection{Structural geometry of DFB rocks}

The DFB rocks exposed in the area are multiply deformed by three phases of deformations, namely $\mathrm{D}_{1 \mathrm{D}}, \mathrm{D}_{2 \mathrm{D}}$, and $\mathrm{D}_{3 \mathrm{D}}$. The dominant planar fabric of the area is a schistosity (that has developed within the quartzite, pelitic schists, hornblende-biotite schist and conglomerate) and a gneissosity (seen within the calc gneiss), which are the result of the first deformation episode $D_{1 D}$. The grade of metamorphism during this deformation has reached up to amphibolite facies, indicated by the presence of staurolite in the pelitic rocks (figure 8a). During this deformation-metamorphism event, the granitic magma could be generated by partial melting (Pitcher 1993 and references therein; Rutter and Neumann 1995; Misra et al. 2009, 2011) and intruded the DFB rocks along with the basement gneiss; though such a statement is purely conjectural and needs to be proved with proper

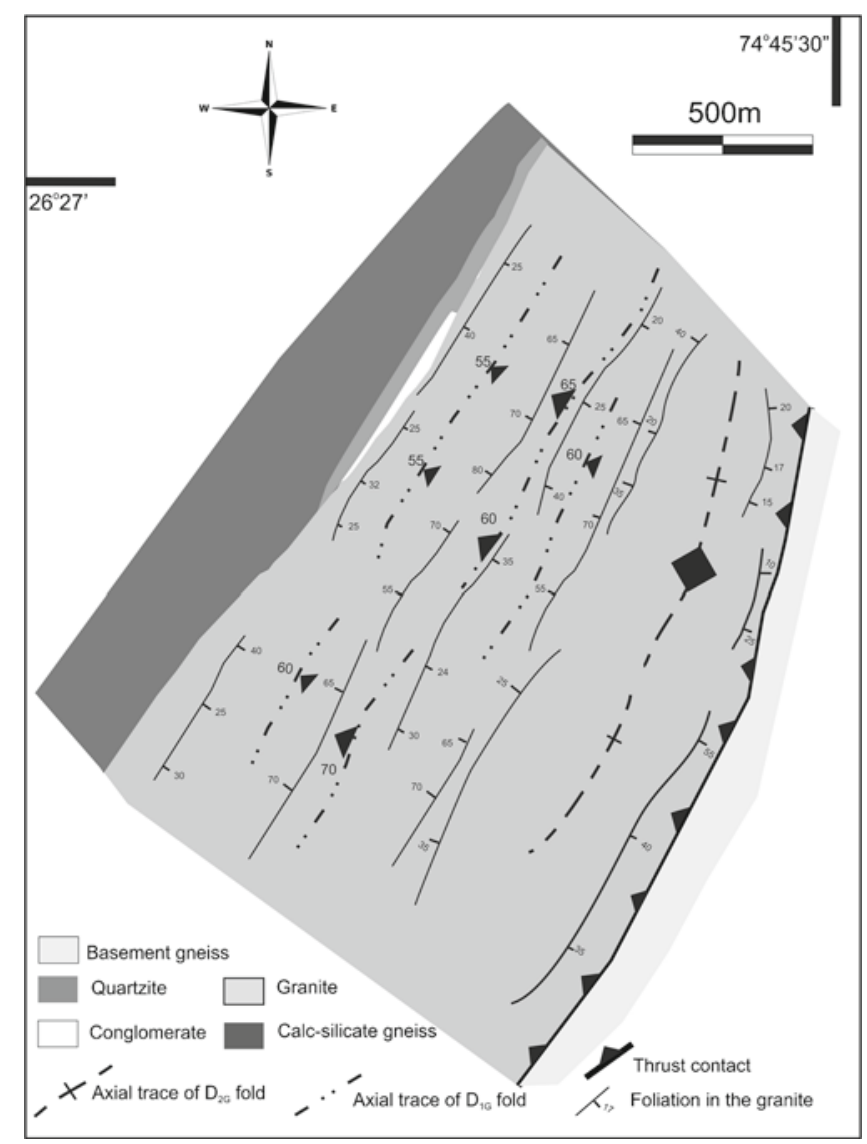

Figure 7. Trend map of the foliation surfaces within granite in sector II, revealing the major mappable axial surfaces. 


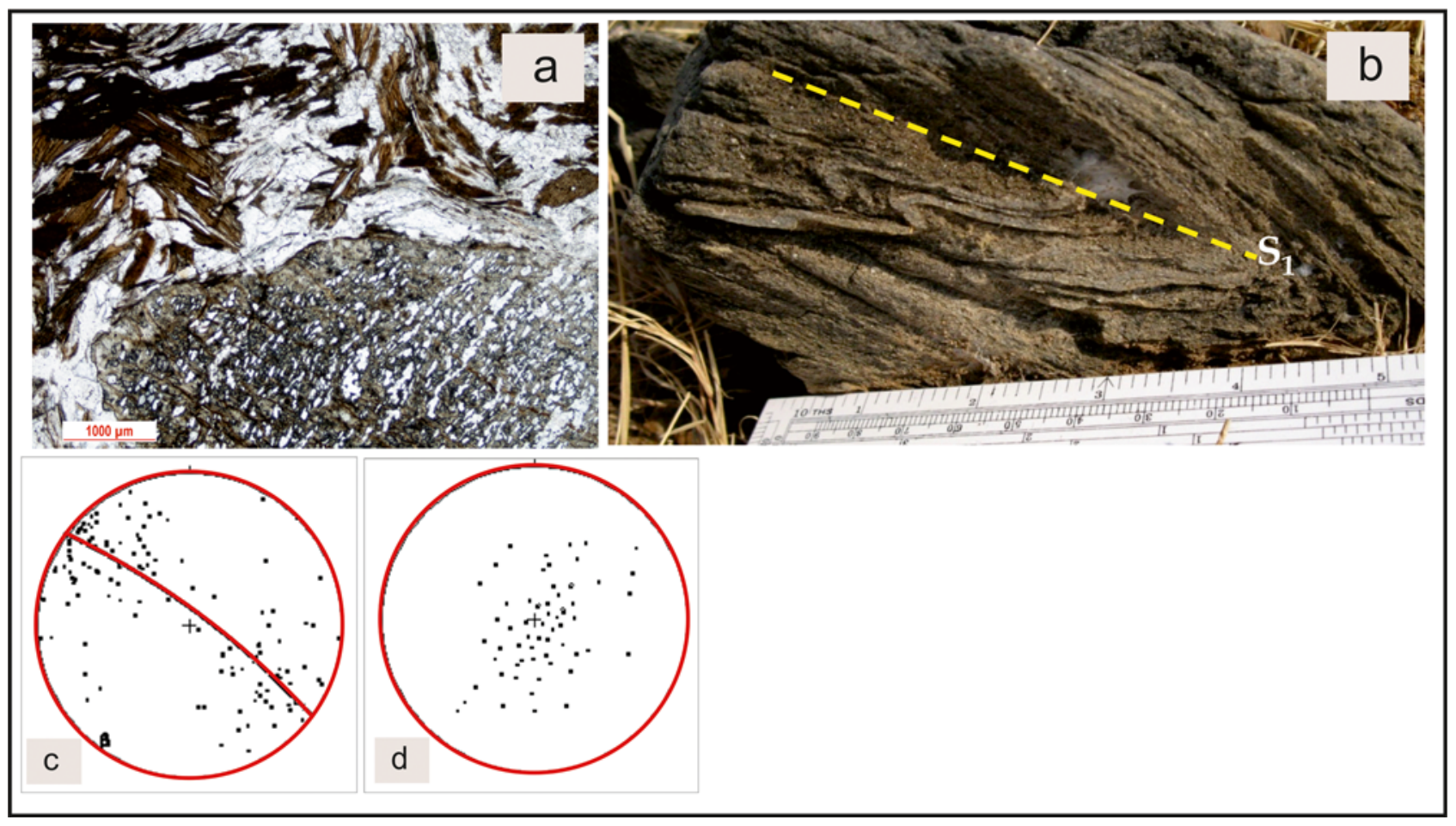

Figure 8. (a) Staurolite porphyroblast showing multi-stage deformation signature. The internal trail of inclusions of quartz are oblique to the crenulated foliation of biotite warping the staurolite porphyroblasts. Note that there are flakes of biotite within the staurolite grain that are approximately parallel to the crenulations cleavage in the rock. (b) The first generation tight folds of bedding in quartzite seen $5 \mathrm{~km}$ west of Srinagar. (c) Equal area projection diagram of 135 poles to compositional planes within quartzite showing a girdle distribution. (d) Equal area projection of 61 lineations syn-kinematic with $\mathrm{D}_{1 \mathrm{D}}$ folds within quartzite of DFB.

geochemical studies, which is not the aim of this paper.

The $\mathrm{D}_{1 \mathrm{D}}$ has produced folds of diverse geometries. Away from the Srinagar granite, within the quartzite the $\mathrm{D}_{1 \mathrm{D}}$ folds are close to tight (figure $8 \mathrm{~b}$ ) and have moderate to gentle plunges due $\mathrm{N}$ or $\mathrm{S}$ on a NNE-SSW trending axial plane. The poles to the compositional planes seen within the quartzite, thought to represent bedding planes, transposed by $\mathrm{D}_{1 \mathrm{D}}$, show a great circle distribution on an equal area projection diagram, whose pole has an attitude of $8^{\circ}$ towards $217^{\circ}$ (figure $8 \mathrm{c}$, table 1 ). The mineral lineations and the fold axes belonging to the $\mathrm{D}_{1 \mathrm{D}}$ generation, when plotted on an equal area projection diagram, show a scatter distribution (figure $8 \mathrm{~d}$ ). The fold axes are more variable in their orientations than the mineral lineations with an overall point concentration, plunging $84^{\circ}$ towards $129^{\circ}$ (table 1 ).

As one moves from west to east, the $\mathrm{D}_{1 \mathrm{D}}$ folds become tighter (nearly isoclinal) and get more inclined. This is attributed to the physical rotation of the $\mathrm{D}_{1 \mathrm{D}}$ folds in response to the continuous compressive stress regime that outlasted the associated metamorphism of the DFB metasediments.

The $D_{2 D}$ folds are the result of this continued collision, with a time lag from $\mathrm{D}_{1 \mathrm{D}}$. The geometry of these folds do not predict a drastic change in the stress regime of the deformation. These folds have folded the $\mathrm{D}_{1 \mathrm{D}}$ schistosity surfaces. The $\mathrm{D}_{2 \mathrm{D}}$ has produced a spaced cleavage within the quartzite and calc gneiss (figure $9 \mathrm{a}$ ) overprinting the $\mathrm{D}_{1}$ foliation surface and a zonal crenulation cleavage within the pelitic-schist (figure $9 \mathrm{~b}$ ). Equal area projections of poles to schistosity/gneissosity planes of $\mathrm{D}_{1 \mathrm{D}}$ generation show that they are distributed along a girdle whose pole has an attitude of $11^{\circ}$ towards $220^{\circ}$ (figure 9c, table 1 ).

The $\mathrm{D}_{3 \mathrm{D}}$ deformation episode has produced open upright folds, developed on gentle limbs of $\mathrm{D}_{2 \mathrm{D}}$ folds; similar in geometry to the $\mathrm{D}_{2 \mathrm{G}}$ folds of the granite within the area. The undifferentiated $\mathrm{D}_{2 \mathrm{D}}$ and $\mathrm{D}_{3 \mathrm{D}}$ fold axes along with congruent puckers when plotted on an equal area projection diagram show that they have low plunges either NNE or SSW directions with a statistical mean orientation of $9^{\circ}$ towards $23^{\circ}$ (figure $9 \mathrm{~d}$, table 1 ).

\subsection{Structural correlation between granite and DFB metasediments}

It can therefore be concluded from the present study that the DFB sediments preserve the imprint 


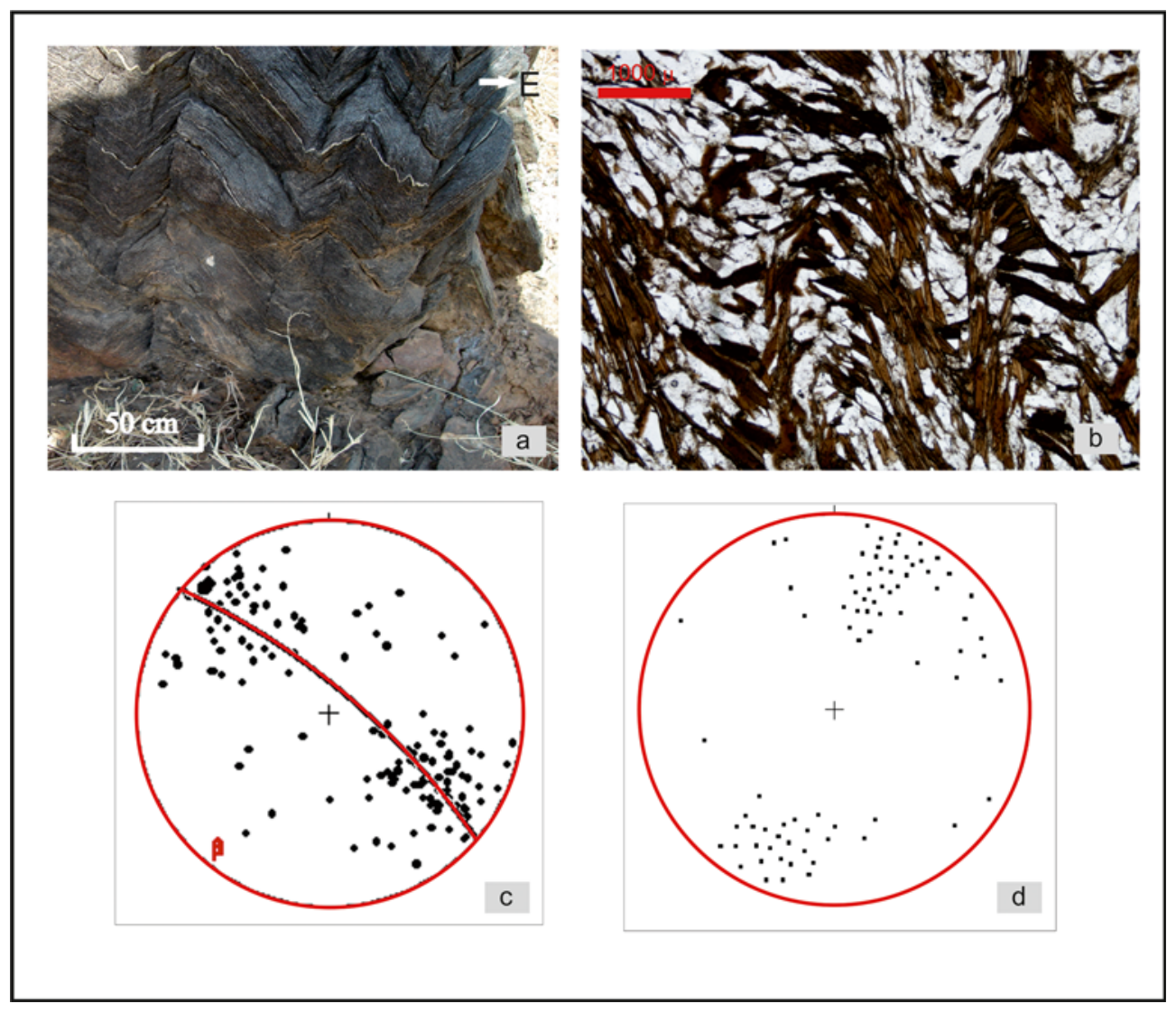

Figure 9. (a) Upright folds of $\mathrm{D}_{3 \mathrm{D}}$ generation folding the gneissic banding within the calc silicate gneiss of DFB, on a section viewed from south. (b) Crenulation cleavage developed within the pelitic schist. These cleavages are parallel to the $\mathrm{D}_{2 \mathrm{D}}$ axial structures. (c) Equal area projection of 145 poles to the $\mathrm{D}_{1 \mathrm{D}}$ generation foliations showing a predominantly girdle distribution. (d) Equal area projection of 81 undifferentiated $\mathrm{D}_{2 \mathrm{D}}$ and $\mathrm{D}_{3 \mathrm{D}}$ fold and pucker axes lineations showing a point concentration.

of one more deformation regime than that of the granite. In fact, the $\mathrm{D}_{3 \mathrm{D}}$ is similar in style and orientation with $\mathrm{D}_{2 \mathrm{G}}$. A look at the orientation figures of the structural elements plotted on equal area projection diagrams also reveals the same. The modal orientation of the axes of $\mathrm{D}_{2 \mathrm{D}}$ and $\mathrm{D}_{3 \mathrm{D}}$ folds taken together is $9^{\circ}$ towards $23^{\circ}$ (figure $9 \mathrm{~d}$ ), which is comparable to the average orientation of the axes of $\mathrm{D}_{2 \mathrm{G}}$ folds within the granite, which is $4^{\circ}$ towards $15^{\circ}$, in sectors I and III (table 1). There is similarity in the distribution pattern of the foliation planes in the granite in sector II and the schistosity of the DFB rocks folded by $\mathrm{D}_{1 \mathrm{G}} / \mathrm{D}_{2 \mathrm{G}}$ and $D_{2 D} / D_{3 D}$ respectively. The pole for the former is $11^{\circ}$ towards $220^{\circ}$ and for the latter is almost horizontal trending $35^{\circ}-215^{\circ}$ (table 1 ). It is only within the sectors I and III in the granite, one finds a statistical orientation of planar fabric having an attitude of $219^{\circ} / 53^{\circ} \mathrm{NW}$, along which mylonitisation has taken place and hence is suggested to be the plane of shear. Statistically the orientations of $\mathrm{D}_{2 \mathrm{D}} / \mathrm{D}_{3 \mathrm{D}}$ generation fold axes match (within the statistical error limits; table 1) to the $\mathrm{D}_{2 \mathrm{G}}$ generation fold axes; both together lie close to the shear plane described above. With these considerations it can be reasonably concluded that the granite must have been emplaced prior to $\mathrm{D}_{2 \mathrm{D}}$ deformation episode. We further suggest from the composite nature of foliation planes within the granite (which was initially a magmatic fabric but later altered to a diastrophic one) the timing of granite emplacement must be late syn- to post-kinematic with $\mathrm{D}_{1 \mathrm{D}}$ deformation (figure 10).

The shape of the granite exposure reveals a maximum thickness at the central regions compared to the southern and northern tips. This enhanced thickness and hence the differential volume of granite could be a reason for a differential expression of strain in response to the same stress regime to which it was subjected. To compensate for the differential strain pattern, lateral faults developed (some of mappable dimensions, figure 2), similar to lateral ramps with horizontal slickenlines on their surfaces indicating a shallow west-to-east transport direction (figure 11a).

Equal area projections of joints and other fractures (figure 11b) reveal that there are three modal distributions of fracture surfaces: two of those 


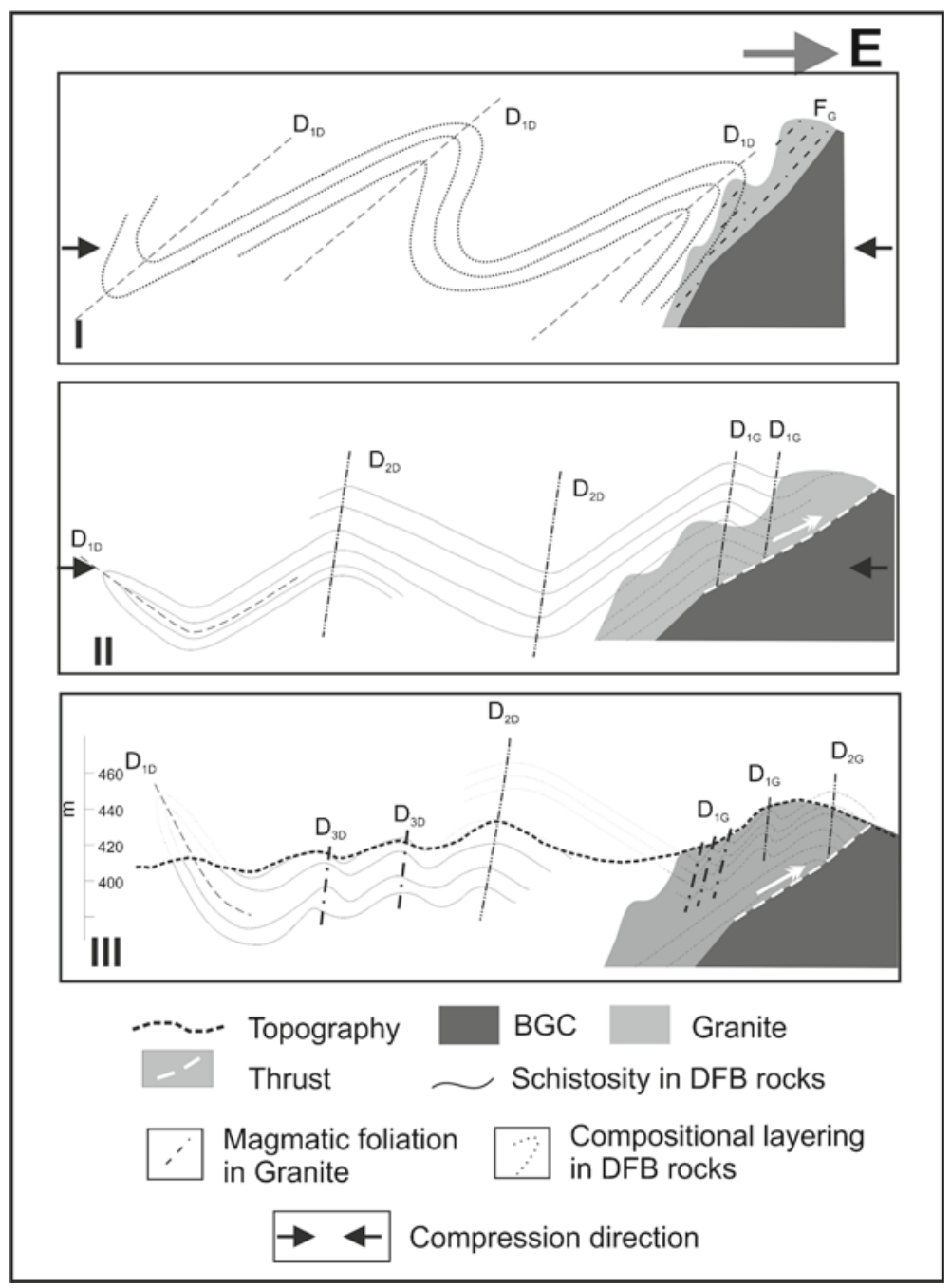

Figure 10. Sequence of emplacement and folding of Srinagar granite along with the DFB rocks. Stage I: Folding of DFB rocks due to $\mathrm{E}-\mathrm{W}$ compression giving rise to the formation of $\mathrm{D}_{1 \mathrm{D}}$ folds in them with the development of a schistosity and/or gneissosity. This is accompanied by emplacement and consolidation of granite. Stage II: Deformation under the continued stress regime resulted in folding of the $\mathrm{D}_{1 \mathrm{D}}$ foliation (within the DFB rocks) along with the magmatic foliation (within the granite) into asymmetric folds of $\mathrm{D}_{2 \mathrm{D}} / \mathrm{D}_{1 \mathrm{G}}$ generation, with easterly vergent axial planes. The contact with BGC acted as a decollement surface and later on as a detachment plane. Continued deformation resulted in exhumation of the granite and its associated metasediments along this detachment plane. Stage III: The upward transport of the rock package resulted in the folding of the gentle limbs of the $\mathrm{D}_{2 \mathrm{D}} / \mathrm{D}_{1 \mathrm{G}}$ folds into upright of $\mathrm{D}_{3 \mathrm{D}} / \mathrm{D}_{2 \mathrm{G}}$ folds, riding piggy back against the detachment plane. The continued $\mathrm{E}-\mathrm{W}$ stress produced lateral ramps during the tectonic transport of the DFB rocks over the basement. Note that the fault being parallel to the sectional view does not show up in the figure.

belong to a single conjugate joint set, with their intersection plunging $27^{\circ}$ towards $218^{\circ}$, similar to the orientations of the later fold axes. The other set is EW trending correlatable with the lateral ramps and transverse faults.

\section{Discussion}

Our work shows that the Srinagar granite is syntectonically emplaced along fracture zones during the deformation-metamorphism of DFB metasediments. Subsequent to its emplacement, the granite exhumed along thrust bringing together the
Delhi metasedimenatry rock sequences over the basement BGC. A comprehensive account of the metamorphic evolution of the rocks along with geochronology of the thermal events needs to be addressed. The area thus awaits a more comprehensive study of the $P-T-t$ history of the rocks along with geochronology to supplement our structural evolutionary model.

The present study shows an example of Precambrian collisional tectonism, where the major collapse direction is east west, with an orogenic core immediate west of Srinagar. The granite, exhumed along subduction-related-faults, has been later cofolded with the DFB metasediments and the entire 


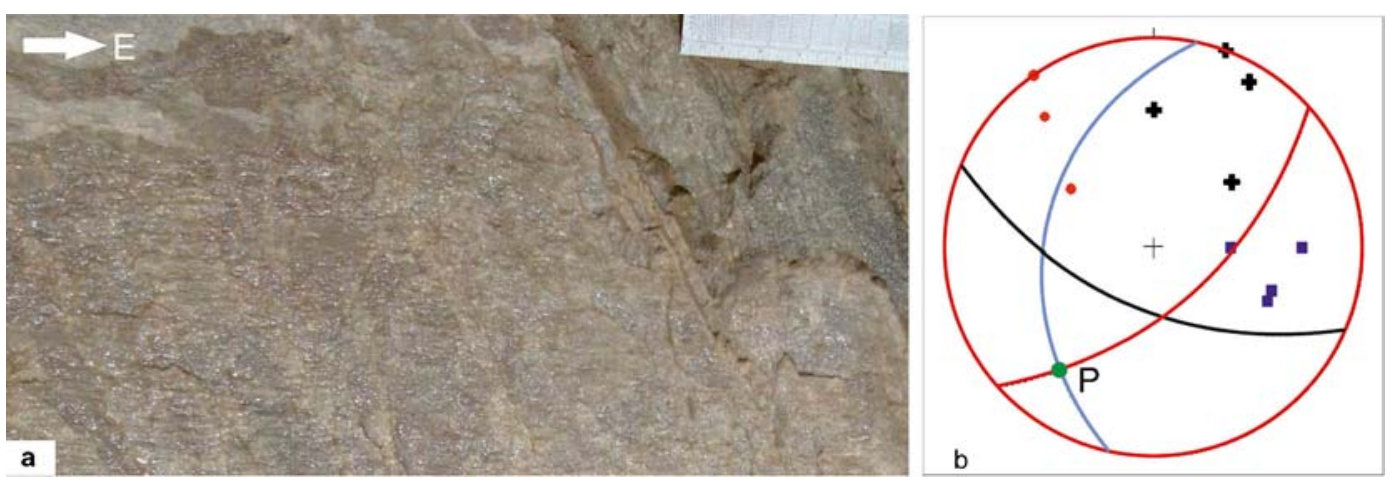

Figure 11. (a) Horizontal slickenlines seen on the E-W vertical fault surfaces looking from south. These lines indicate the tectonic transport direction along the westerly dipping thrusts. (b) Equal area projection of three sets of fracture planes seen in sector II. The great circles represent the average fracture orientation for each set. The fractures plotted by red dots are southeasterly dipping and their average orientation is given by red great circle. The blue squares represent northwesterly dipping fractures with an average orientation given by the blue coloured great circle. These two form a conjugate set with their point of intersection (the green dot at P) matching the fold axis. The black crosses represent the measured fault planes which are transverse to the length of the granite. These are WNW-ESE trending with a subvertical dip due SSW, represented by the black coloured great circle.

package carried over the basement gneisses. The separating surface acted as a décollement surface, thereby keeping the basement unaffected by the deformation regime; much alike to thin skinned tectonism. The development of the fabric reveals that the same tectonic stress regime persisted throughout Delhi orogeny, producing folds of diverse generations but taken together representing a single spectrum of progressive deformation. This is in contrast to the deformation regime seen along the western margin of the SDFB, where two episodes of finite strains have been reported (Dasgupta et al. 2012). We therefore like to conclude that the collapse of the different segments of Delhi basins had a different tectono-evolutionary history. The time period between 1470 and $850 \mathrm{Ma}$ is generally taken to be the time frame of the Delhi orogeny. However, Roy and Kroner (1996) and Pandit et al. (2003) consider the age of termination of Delhi orogeny at $750 \mathrm{Ma}$ from the charnockites which occur within and are younger to the DFB rocks.

Several proposals have been put forward by geoscientists through ages regarding granite emplacement models like diking, ballooning, sheeting, and stopping (see Hutton 1982, 1988; Castro 1987; Guineberteau et al. 1987; Hutton et al. 1990; Clarke 1992; Pitcher 1993; Ingram and Hutton 1994; Vigneresse 1995; Bouchez 1997; Castro et al. 1999; Paterson and Schmidt 1999; Schmidt and Paterson 2000; Richards 2001 and Paterson 2006 for a complete review). Granite magma ascent and emplacement have also been controlled by crustal scale shear zones (D'Lemos et al. 1992; Hutton and Reavy 1992; Brown 1994; Vigneresse 1995; Roma'n-Berdiel et al. 1997; Rosenberg 2004) and have been modelled by Corti et al. (2005). Ferre' et al. (2012) (with a good compilation of references therein) provide a detailed discussion on how thrusts act as magma propagation pathways. We present a natural example of the model construed by Ferre' et al. (2012) showing the granite exhumed along a thrust. We also discuss that in such a condition, formation of lateral ramps has resulted in partitioning of strain within the granite.

\section{Acknowledgements}

The authors would like to thank the help and support extended by the local people for this work. ND wishes to acknowledge the grant received from UGC (Sanction No. F.PSW-070/09-10 (ERO) dated 18.10.2009). The authors also like to express their gratitude to Dr S Pal of Durgapur Government College, West Bengal (who refrained from being an author of this paper) for discussions held on and off the field. The authors are also thankful to Prof. D Mukhopadhyay for his critical comments, advice and guidance. The suggestions and comments from the anonymous reviewers are also duly acknowledged.

\section{References}

Biswal T K 1993 Structural history of Barotia group near Barr, Pali District, Rajasthan; Indian Minerals 47(2) 123-130.

Bouchez J L, Hutton D and Stephens W E 1997 Granite: From melt segregation to emplacement fabrics; Kluwer Academic Publisher, Dordrecht, 356p.

Brown M 1994 The generation, segregation, ascent and emplacement of granite magma: The migmatite-tocrustally derived granite connection in thickened orogens; Earth Sci. Rev. 36 83-130. 
Castro A 1987 On granitoid emplacement and related structures: A review; Geological Rundsch 76 101-124.

Castro A, Fernandez C and Vigneresse J L 1999 Understanding granites: Integrating new and classical techniques; Geol. Soc. London Spec. Publ. 168 275p.

Choudhary A K, Gopalan K and Shastry C A 1984 Present status of the geochronology of the Precambrian rocks of Rajasthan; Tectonophys. 105 131-140.

Clarke D B 1992 Granitoid rocks; Chapman and Hall, New York, Topics in the Earth Science $\mathbf{7} 283$.

Corti G, Moratti G and Sani F 2005 Relations between surface faulting and granite intrusions in analogue models of strike-slip deformation; J. Struct. Geol. 27 1547-1562.

D'Lemos R S, Brown M and Strachan R A 1992 Granite magma generation, ascent and emplacement within a transpressional orogen; J. Geol. Soc. London 149 487-490.

Dasgupta N, Sen J, Pal T and Ghosh T 2009 Nature and time of emplacement of a pegmatoidal granite within the Delhi Fold Belt near Bayalan, Rajasthan, India; Geophysical Research Abstract, EGU, 11.

Dasgupta N, Pal T, Sen J and Ghosh T 2011 Characteristics of pegmoidal granite exposed near Bayalan, Ajmer district, Rajasthan; J. Earth Syst. Sci. $120617-$ 626.

Dasgupta N, Mukhopadhyay D and Bhattacharyya T 2012 Analysis of superposed strain: A case study from Barr Conglomerate in the South Delhi Fold Belt, Rajasthan, India; J. Struct. Geol. 34 30-42.

Deb M, Thorpe R I, Kristic D, Corfu F and Davis D W 2001 Zircon $\mathrm{U}-\mathrm{Pb}$ and galena $\mathrm{Pb}-\mathrm{Pb}$ isotope evidence for an approximate $1.0 \mathrm{Ga}$ terrane constituting the western margin of the Aravalli-Delhi orogenic belt, northwestern India; Precamb. Res. 108 195-213.

Fareeduddin and Kroner A 1998 Single zircon age constraints on the evolution of Rajasthan granulite, In: The Indian Precambrian (ed.) Paliwal B S (Jodhpur: Scientific Publishers), pp. 547-556.

Ferre' E C, Galland O, Montanari D and Kalakay T J 2012 Granite magma migration and emplacement along thrusts; Int. J. Earth Sci., doi: 10.1007/s00531-0120747-6.

Gangopadhyay A and Mukhopadhyay D 1984 Structural geometry of the Delhi Supergroup near Sendra; In: Geological evolution of peninsular India (ed.) Saha A K, Recent Researches in Geology (Delhi: Hindustan Publishing Corporation), pp. 45-60.

Gopalan K, Trivedi J R, Merh S S, Patel P P and Patel S G $1979 \mathrm{Rb} \pm \mathrm{Sr}$ age of Godhra and related granites, Gujarat (India); Proc. Indian Acad. Sci. (Earth Planet. Sci.) $\mathbf{8 8 \mathbf { A }}$ $7-17$.

Guineberteau B, Bouchez J L and Vigneresse J L 1987 The Mortagne granite pluton (France) emplaced by pull apart along a shear zone structural and gravimetric arguments and regional implication; Geol. Soc. Am. Bull. $99763-$ 770 .

Gupta P and Bose U 2000 An update of the geology of the Delhi Supergroup in Rajasthan; Geol. Soc. India Spec. Publ. 55 287-306.

Gupta P 2004 Ancient Orogens of Aravalli Region; Geol. Soc. India Spec. Publ. 84 150-205.

Heron A M 1953 The geology of central Rajputana; Geol. Surv. India Memoir $\mathbf{7 9} 389$.

Hutton D H W 1982 A tectonic model for the emplacement of the main Donegal granite, NW Ireland; J. Geol. Soc. London 139 615-631.

Hutton D H W 1988 Igneous emplacement in a shear-zone termination: The biotite granite at Strontian, Scotland; Geol. Soc. Am. Bull 100 1392-1399.
Hutton D H W, Dempster T J, Brown P E and Becker S M 1990 A new mechanism of granite emplacement: Rapakivi intrusions in active extensional shear zones, south Greenland; Nature 343 452-454.

Hutton D H W and Reavy R J 1992 Strike slip tectonics and granite petrogenesis; Tectonics 11 960-967.

Ingram G M and Hutton D H W 1994 The Great Tonalite Sill: Emplacement into a contractional shear zone and implications for Late Cretaceous to Early Eocene tectonics in southeastern Alaska and British Columbia; Geol. Soc. Am. Bull. 106 715-728.

Misra S, Burlini L and Burg J-P 2009 Strain localization and melt segregation in deforming metapelites; Phys. Earth Planet. India 117 173-179.

Misra S, Burg J-P and Mainprice D 2011 Effect of finite deformation and deformation rate on partial melting and crystallization in metapelites; J. Geophys. Res. 116, doi: 10.1029/2010JB007865.

Mukhopadhyay D and Dasgupta S 1978 Delhi pre-Delhi relations near Badnor, central Rajasthan; Indian J. Earth Sci. 5 183-190.

Mukhopadhyay D 1989 Structural history of the central section of the Delhi orogenic belt; Proc. 28th Int. Geol. Cong., Abstract 2 479-480.

Mukhopadhyay D and Matin A 1991 Early major folds in the Delhi Supergroup around Hatankhera, Ajmer district, Rajasthan; Indian J. Geol. 63 67-74.

Murthy T V V G R K and Bhargava L R 1972 The deformation of barr conglomerate; J. Geol. Soc. India 13 66-74.

Naha K, Mukhopadhyay D K, Mohanty R, Mitra S K and Biswal T K 1984 Significance of contrast in the early stages of the structural history of the Delhi and the pre-Delhi rock groups in the Proterozoic of Rajasthan, western India; Tectonophys. 105 193-206.

Naha K and Mohanty S 1988 Response of basement and cover rocks to multiple deformations: A study from the Precambrian of Rajasthan, western India; Precamb. Res. 42 77-96.

Pandit M K, Carte L M, Ashwal L D, Tucker R D, Torsvik T H, Jamtveit B and Bhushan S K 2003 Age, petrogenesis and significance of $1 \mathrm{Ga}$ granitoids and related rocks from the Sendra area, Aravalli Craton, NW India; J. Asian Earth Sci. 22 363-381.

Paterson S R and Schmidt K 1999 Is there a close spatial relationship between faults and plutons? J. Struct. Geol. 21 1131-1142.

Paterson S R 2006 Close spatial relationship between plutons and shear zones: Comment; Geology $3372 \mathrm{p}$.

Pitcher W S 1993 The nature and origin of granite (London: Blackie Academic and Professional Press), pp. 183-184.

Richards J P 2001 Discussion of "Is there a close spatial relationship between faults and plutons?" by S.R. Paterson and K.L. Schmidt; J. Struct. Geol. 23(12) 2025-2027.

Roma'n-Berdiel T, Gapais D and Brun J P 1997 Granite intrusion along strike-slip zones in experiment and nature; Am. J. Sci. 297 651-678.

Rosenberg C L 2004 Shear zones and magma ascent: A model based on a review of the Tertiary magmatism in the Alps; Tectonics 23 TC3002, doi: 10.1029/2003TC001529.

Roy A B and Kröner A 1996 Single zircon evaporation ages constraining the growth of the Archaean Aravalli craton, northwestern Indian shield; Geol. Mag. 133 333-342.

Rutter E H and Neumann D H K 1995 Experimental deformation of partially molten westerly granite under fluidabsent conditions, with implications for the extraction of granitic magmas; J. Geophys. Res 100(B8) 15,69715,715 . 
Schmidt K L and Paterson S R 2000 Analyses fail to find coupling between deformation and magmatism; EOS 81(197) 202-203.

Sengupta S 1988 Development of successive sets of structures in a process of continuous deformation: A case study from the Delhi metasediments near Kharwa, Ajmer Dt., Rajasthan, India; Indian J. Earth Sci. 15 116-131.

Sinha Roy S 1984 Precambrian crustal interaction in Rajasthan, NW India; In: Proc. Seminar on Crustal evolution of Indian shield and its bearing on metallogeny; Indian J. Earth Sci., pp. 84-91.

Sinha-Roy S 1988 Proterozoic Wilson cycles in Rajasthan; In: Precambrian of the Aravalli mountain range (ed.) Roy A B, Geol. Soc. India Memoir 7 95-108.

Sinha-Roy S 2004 Intersecting Proterozoic transpressional orogens, major crustal and suspect terranes in Rajasthan craton: A plate tectonic perspective; Geol. Surv. India Spec. Publ. 84 207-226.

Tobisch $\mathrm{O} \mathrm{T}$, Collerson $\mathrm{K}$ D, Bhattacharya $\mathrm{T}$ and Mukhopadhyay D 1994 Structural relationship and Sm$\mathrm{Nd}$ isotope systematics of polymetamorphic granitic gneisses and granitic rocks from central Rajasthan, India: Implications for the evolution of the Aravalli craton; Precamb. Res. 65 319-339.

Vigneresse J L 1995 Control of granite emplacement by regional deformation; Tectonophys. 249 173186.

Volpe A M and Macdougall J D 1990 Geochemistry and isotopic characteristic of mafic (Phulad ophiolite) and related rocks in the Delhi Supergroup, Rajasthan, India: Implications for rifting in the proterozoic; Precamb. Res. 48 167-191. 